\title{
Prevalence of anemia in children 6-59 months old in the state of Pernambuco, Brazil
}

\author{
Mônica M. Osório, ${ }^{1,} 2$ Pedro I. C. Lira, ${ }^{1}$ Malaquias Batista-Filho, ${ }^{1}$ \\ and Ann Ashworth ${ }^{2}$
}

ABSTRACT Objective. To determine the prevalence of anemia in children 6-59 months old in Pernambuco, a state in northeastern Brazil, so as to help guide health and nutrition policies there.

Methods. In 1997 a representative sample of 777 young children had their hemoglobin concentration measured. The sampling process was in three stages. First, 18 municipalities were randomly selected to represent the state and its three geographic areas (metropolitan region of Recife, urban interior, and rural interior). Next, using census lists, 45 census sectors were randomly chosen. Finally, 777 children aged 6-59 months old were selected. Blood was collected by venipuncture, and hemoglobin was measured with a portable hemoglobinometer. In the analysis, prevalence was weighted to reflect the census age distribution.

Results. The prevalence of anemia among children 6-59 months old was $40.9 \%$ for the state as a whole. Prevalence in the metropolitan region of Recife was $39.6 \%$, and it was $35.9 \%$ in the urban interior. The rural interior had the highest prevalence, $51.4 \%$. Prevalence was twice as high in children aged 6-23 months as among those 24-59 months old, $61.8 \%$ vs. $31.0 \%$ $\left(\chi^{2}=77.9, \mathrm{P}<0.001\right)$. The mean hemoglobin concentrations in the younger and older age groups were $10.4 \mathrm{~g} / \mathrm{dL}$ (standard deviation $(S D)=1.5)$ and $11.4 \mathrm{~g} / \mathrm{dL}(S D=1.4)$, respectively. There was no statistically significant difference between the sexes in terms of prevalence.

Conclusions. This is the first statewide assessment of anemia prevalence among young children in Brazil. Given the very high prevalence of anemia among the children studied in Pernambuco, especially those in the age group of 6-23 months, public health interventions are needed.

Key words Anemia, iron, hemoglobin, child health, Brazil.

Iron deficiency anemia is a public health problem in both developing and industrialized countries, and more than 2 billion people around the world are estimated to be anemic (1).
Iron deficiency anemia adversely affects health, cognitive development, school achievement, and work performance. While prevalence data in Brazil are limited, reports from rural Per-

Recife - PE - Brazil; telephone: 5581 2718470; fax 5581 2718473; e-mail: mosorio@nutricao.ufpe.br

Universidade Federal de Pernambuco, Departamento de Nutrição, Recife, Pernambuco, Brazil. Send correspondence to: Mônica Maria Osório, Departamento de Nutrição, Universidade Federal de Pernambuco, 50670-860 Cidade Universitária,
2 London School of Hygiene and Tropical Medicine, Public Health Nutrition Unit, London, United Kingdom. nambuco (2), rural Bahia (3), urban Paraíba (4), and the city of São Paulo (5) indicate that $35 \%$ to $40 \%$ of young children are anemic. In the city of São Paulo, trend data reveal an increasing prevalence of anemia despite improved environmental conditions and health care and a decreasing prevalence of malnutrition $(5,6)$.

The northeast of Brazil-which includes the state of Pernambuco-is the 
poorest region in the country and thus may be expected to have the highest anemia prevalence. This study was conducted to determine the prevalence of anemia in Pernambuco and its three geographic areas in order to guide health policy and future interventions. The study focused on the prevalence in a representative sample of children 6-59 months old.

\section{SUBJECTS AND METHODS}

\section{Location}

Pernambuco has an area of approximately $100000 \mathrm{~km}^{2}$ and a population of over 7 million, of whom $10 \%$ are children under 5 years of age (7). Infant mortality in Pernambuco is much higher than the national rate, 58.2 vs. 34.6 per 1000 live births, and illiteracy among those aged $>15$ years is twice the national figure, $26.4 \%$ vs. $13.3 \%$ (7).

The population of Pernambuco is predominantly urban, residing primarily in and around the capital of Recife or in smaller cities and towns in the interior of the state. On the east, the state borders on the Atlantic Ocean, and in that part of Pernambuco the climate is hot and humid, with sugar cane constituting the most significant crop. Among sugar-cane workers and their families, living conditions are poor, wages are low, and amenities are few, and those persons have little opportunity to grow their own food. In the towns in the interior, small businesses provide employment, and there are local light industries. Moving westward in the state, the climate becomes increasingly dry, and most families are subsistence farmers who struggle to eke out a livelihood in the harsh conditions. During times of drought, many migrate to Recife, which is a busy industrial city on the Atlantic coast and a popular tourist destination with extremes of affluence and poverty. Pernambuco's geographic and socioeconomic diversity is reflected in considerable differences in the quality of life within the state, with the rural areas having the worst health and nutrition indices (8). Malaria is not found in northeastern Brazil and thus does not contribute to the anemia prevalence there.

\section{Study design and data collection}

The data were collected during February-May 1997. The survey was cross-sectional, and the sample was representative of the state of Pernambuco and its three geographic areas: the metropolitan region of Recife, the urban interior, and the rural interior.

Subject selection. Sampling was carried out in three stages (9). The first stage was proportional systematic random sampling, in which 18 out of a total of 178 municipalities were selected to reflect the population distribution of the state. For the second stage, the census sectors in each municipality were separated according to their urban or rural designation, and a total of 45 census sectors (out of 2655 ) were selected by systematic random sampling. There were 16 sectors in the metropolitan region of Recife, 17 in the urban interior, and 12 in the rural interior. Each census sector had approximately 200 households. Finally, households in each selected sector were visited to identify children aged 6-59 months old. The starting point in each sector was randomly determined from the census map, selecting one block at random and then one corner of that block, also at random. Then, in a clockwise direction, households were visited one by one until the required sample was selected. A total of 777 children were selected, averaging 17 per sector.

Blood collection. Permission of the mother or other custodian was first sought for blood collection. Venous blood was collected from an antecubital vein by trained fieldworkers. The hemoglobin concentration was measured with a portable hemoglobinometer (HemoCue Ltd, Sheffield, United Kingdom), following the manufacturer's instructions.
Ethical considerations. This study had the approval of the Ethical Committee of the Federal University of Pernambuco. Children diagnosed as anemic were treated for 6 months by the research team with $3 \mathrm{mg}$ elemental iron (as sulfate) $/ \mathrm{kg} /$ week and referred to their local clinic for continuing treatment.

\section{Data analysis}

Anemia was defined as a hemoglobin concentration $<11 \mathrm{~g} / \mathrm{dL}$, grouped as follows: severe anemia, $<7.0 \mathrm{~g} / \mathrm{dL}$; moderate anemia, 7.0 to $8.9 \mathrm{~g} / \mathrm{dL}$; and mild anemia, 9.0 to $10.9 \mathrm{~g} / \mathrm{dL}$ (10). We divided the age range of 6-59 months into five subgroupings, and we weighted the overall prevalences for the state and for each of the three geographic areas according to the actual population of children in these age bands as reported in the census for the state (7).

In the statistical analyses, differences for categorical variables were assessed by the chi-square $\left(\chi^{2}\right)$ test, and the $\chi_{\text {trend }}^{2}$ was used for linear trend. For these tests the unweighted prevalence values were used. For continuous variables, the $t$ test and one-way analysis of variance (ANOVA) were used to test for significant differences in means, and linear regression was applied to test for linear trends. Statistical significance was taken as $P<0.05$. The statistical software package used was Stata version 5.0 (11).

\section{RESULTS}

\section{Prevalence of anemia}

Table 1 shows the prevalence of anemia by age, sex, and geographic area. Overall, $40.9 \%$ of the children studied were anemic. The highest prevalence was in the rural interior $(51.4 \%)$, and this was substantially higher $\left(\chi^{2}=\right.$ $13.77, P<0.001)$ than in the metropolitan region of Recife (39.6\%) and the urban interior (35.9\%).

The prevalence of anemia in children 6-23 months old was twice as 
TABLE 1. Prevalence of anemia by age group and sex for the state as a whole and for geographic areas, Pernambuco, Brazil, 1997a

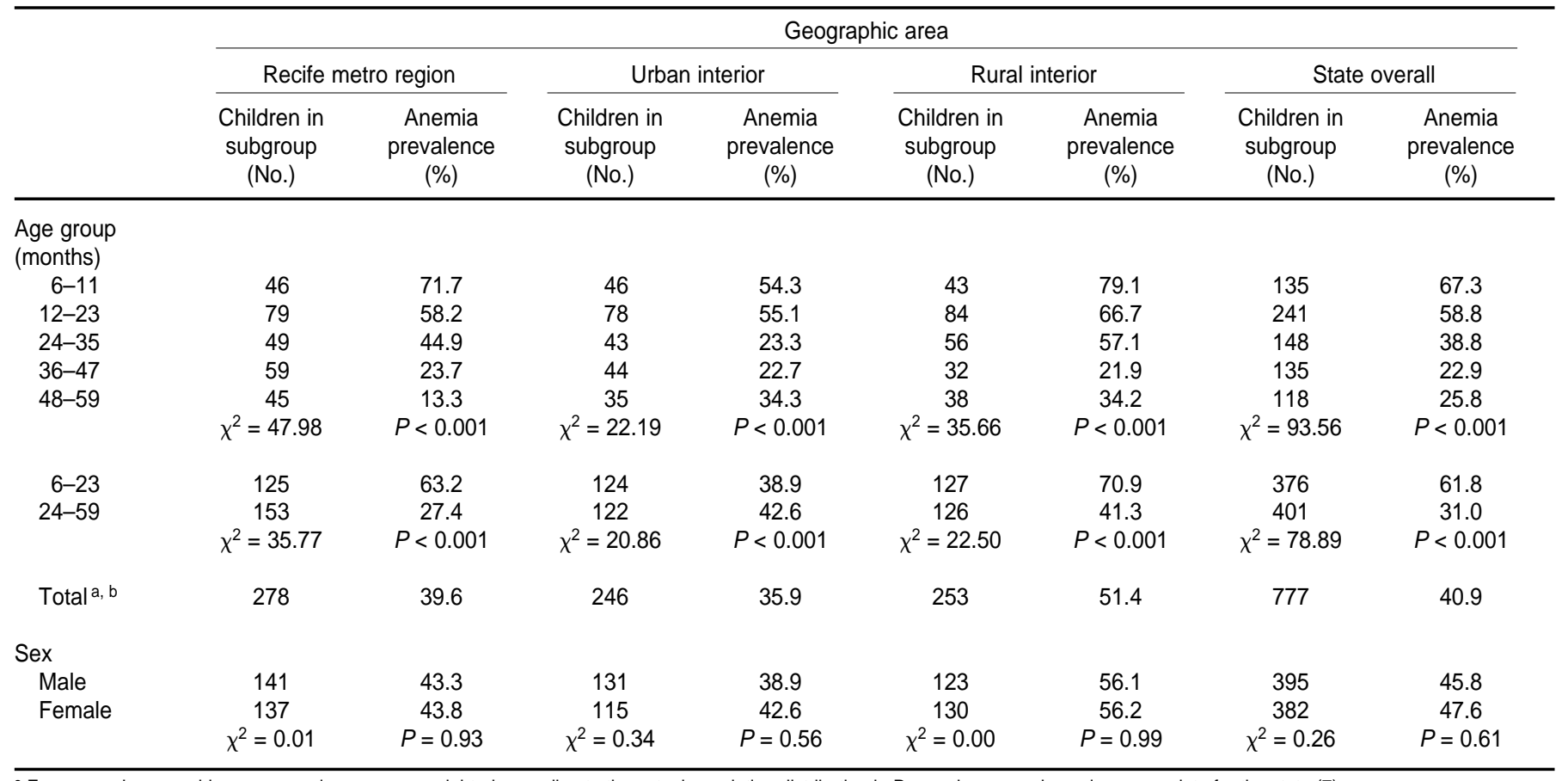

\footnotetext{
${ }^{a}$ For age and geographic area, prevalences were weighted according to the actual population distribution in Pernambuco, as shown in census data for the state (7).
}

b Statistical difference between geographic areas: $\chi^{2}=13.77, P<0.001$.

high as among children aged $24-59$ months, $61.8 \%$ vs. $31.0 \%$. The decreasing trend with age was significant $\left(\chi_{\text {trend }}^{2}=9.86, P<0.001\right)$, and was found in each of the three areas. Anemia prevalence was similar in boys and girls.

\section{Hemoglobin concentration}

Table 2 shows the mean hemoglobin concentrations by age, sex, and geographic area. The overall mean value in children aged 6-59 months was $10.9 \mathrm{~g} / \mathrm{dL}$. The mean value in the rural interior was $10.6 \mathrm{~g} / \mathrm{dL}$, compared with $11.0 \mathrm{~g} / \mathrm{dL}$ for the metropolitan region of Recife and $11.2 \mathrm{~g} / \mathrm{dL}$ for the urban interior. The overall mean hemoglobin concentration was $1.0 \mathrm{~g} / \mathrm{dL}$ higher in children aged 24-59 months than it was among the younger children in the study. The trend test by age was highly significant $(t=11.55, P<0.001)$.

Figure 1 shows the distribution of hemoglobin concentration by geographic area. For children in the rural interior, the curve is shifted to the left by about 0.5 standard deviation (SD) units.

The weighted prevalence of moderate anemia was $10.6 \%$ in the rural interior, and $6.0 \%$ in the two other areas. For severe anemia, the weighted prevalence was $1.3 \%$ in the rural interior and $1.1 \%$ in the metropolitan region of Recife. No child in the urban interior was severely anemic.

Figure 2 shows the distribution of hemoglobin concentration for the two age groups, 6-23 months and 24-59 months. For the younger children, the curve is shifted to the left by almost $1 \mathrm{SD}$. The prevalence of moderate anemia in the younger group was $14.7 \%$, and it was $5.2 \%$ in the older group. For severe anemia, the prevalence in these two respective age groups was $1.2 \%$ and $0.5 \%$.

\section{DISCUSSION}

The $40.9 \%$ overall anemia prevalence that we found among Pernambu- can children is a public health concern. Of particular note is the prevalence of $51.4 \%$ in the rural interior, versus $39.6 \%$ in the metropolitan region of Recife and $35.9 \%$ in the urban interior. The main reasons for the differences we found between rural and urban areas are likely to be: a) lower consumption of heme iron in rural areas due to poverty, limited rearing of livestock, and poor distribution networks for meat and other animal products and $b$ ) lower consumption of vitamin $C$ in rural areas where local fruit and vegetable production is constrained by arid conditions or, in the case of sugar-cane workers, lack of land rights, which precludes domestic food production (8). Sanitation and water supplies are poor in rural areas (8), so higher rates of infections and parasitic diseases can also be expected $(8,12)$.

Anemia prevalence was twice as high in children 6-23 months old compared to those aged 24-59 months, and similar findings have been reported by others $(5,13,14)$. Iron requirements are related to growth velocity and so 
TABLE 2. Mean hemoglobin concentration ( $\mathrm{g} / \mathrm{dL}$ ) and standard deviation (SD) by age group and sex for the state as a whole and for geographic areas, Pernambuco, Brazil, 1997

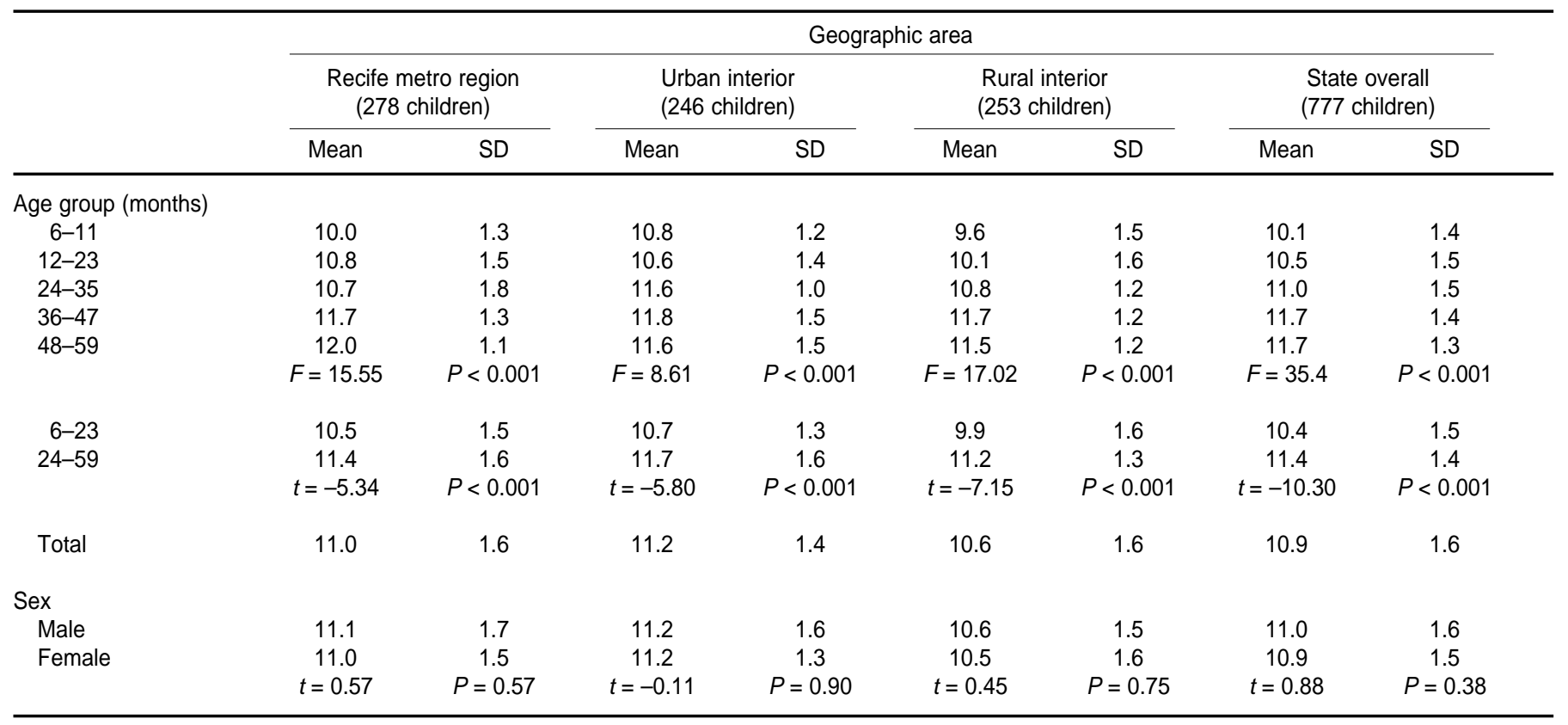

FIGURE 1. Distribution of hemoglobin concentration by geographic area, Pernambuco, Brazil, 1997: metropolitan region of Recife (MRR), urban interior (UI), and rural interior (RI)

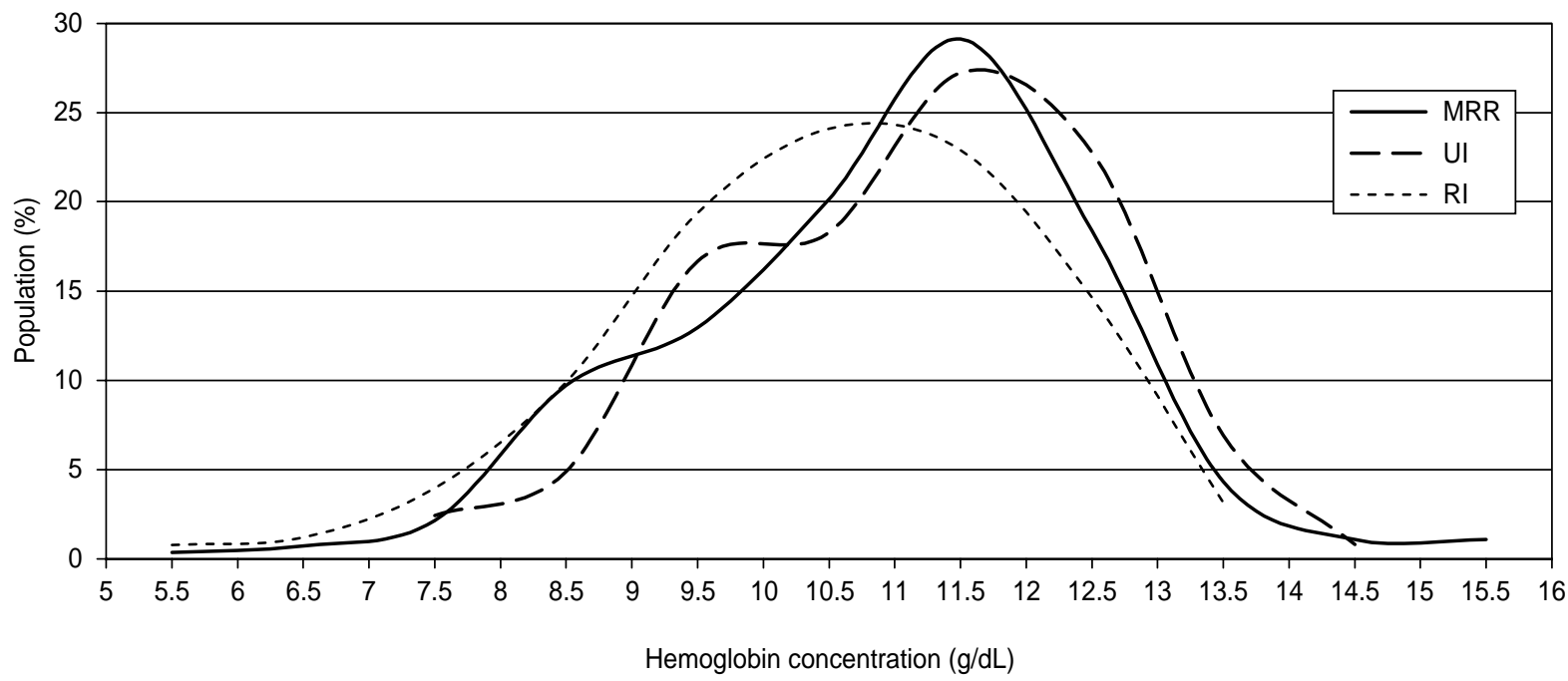

requirements per $\mathrm{kg}$ of body weight decrease with age. Therefore, there may be a physiological explanation for the fall in anemia prevalence with age. Iron intakes are also likely to improve with age as a result of a more varied diet, including the introduction of meat and other heme-containing foods.
Infections depress iron absorption (15), and the prevalence of infections is less in older children (16). Thus the significant decline in anemia prevalence with age in this Pernambuco population is highly credible.

Whether a single cutoff of $11 \mathrm{~g} / \mathrm{dL}$ is appropriate for all age groups is de- batable, and some investigators have called for age-specific cutoffs (17). In "normal" populations-in which deficiencies of iron, folate, and vitamin $\mathrm{B}_{12}$ have either been excluded or are unlikely-measurements of hemoglobin concentration give median values for young children of about $12.5 \mathrm{~g} / \mathrm{dL}$ and 
FIGURE 2. Distribution of hemoglobin concentration by age, Pernambuco, Brazil, 1997

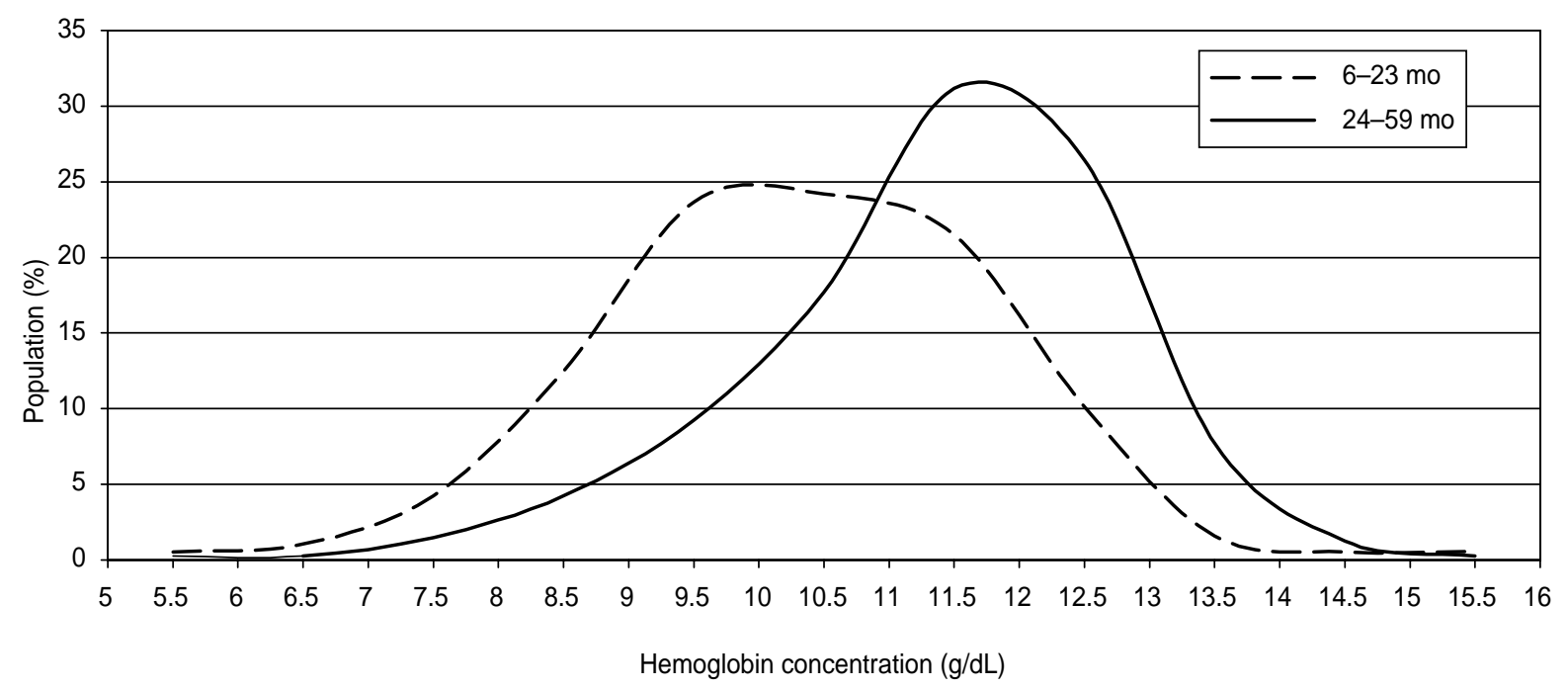

a lower limit of normality of about 11 $\mathrm{g} / \mathrm{dL}$ (17-19). These studies, however, also reveal a slow but gradual rise in hemoglobin concentration, starting from the age of 3 months. Dallman and Siimes (19) reported that at 6 months of age, the lower level of normality is $11.1 \mathrm{~g} / \mathrm{dL}$, increasing to $11.3 \mathrm{~g} / \mathrm{dL}$ at 59 months. Had we used a cutoff of $11.2 \mathrm{~g} / \mathrm{dL}$ (instead of $11.0 \mathrm{~g} / \mathrm{dL}$ ) for the age group of $24-59$ months, the prevalence of anemia in this age group would be $33.3 \%$, rather than the $31.0 \%$ reported in Table 1 . This is a relatively small effect. A difference of $0.2 \mathrm{~g} / \mathrm{dL}$ between the two age groups, however, may be conservative, as larger changes with age were found by Brault et al. (17). Sherriff et al. (20) have recently suggested $10 \mathrm{~g} / \mathrm{dL}$ as the cutoff for anemia in children aged 12-18 months, based on the fifth centile for a large cohort of children in the United Kingdom. Their sample, however, did not exclude iron-deficient children, and the data may be unrepresentative of normal nonanemic populations (18).

Even if age-specific cutoffs were to be used, this does not solve the problem of assessing the true prevalence of anemia, as no single cutoff at any age can distinguish anemic from nonanemic individuals. This is because the hemoglobin distribution curves of anemic and nonanemic subjects overlap.
Thus some anemic individuals have hemoglobin concentrations in the normal range and will not be diagnosed, whereas some normal individuals will be misclassified as anemic (21). For these reasons, additional indicators of deficiency have been advocated, such as serum ferritin, transferrin saturation, and erythrocyte protoporphyrin (21-23). When multiple indicators of iron status are used, anemia prevalence estimates are lower (24). Multiple indicators, however, are unusual in large population surveys.

Race-specific cutoffs have been suggested (25), blacks having hemoglobin concentrations about $0.5 \mathrm{~g} / \mathrm{dL}$ lower than whites and Orientals (25-27). In Pernambuco, the population is mostly of mixed heritage, with no obvious differences in racial composition in the different parts of the state. Whether a lower cutoff is appropriate for this mixed-race population is not known.

Despite the difficulties in assessing anemia, we feel confident that the high prevalence of anemia in Pernambuco is real, and thus interventions are warranted. The urgency is particularly great among rural children and those 6-24 months old.

One potential intervention is to use iron and fortify the milk currently distributed through the national assistance program for malnourished preg- nant women and children. In the city of São Paulo, the provision of milk fortified with iron and vitamin $C$ to children 6-18 months old was associated with a reduction in anemia from $72.6 \%$ to $38.9 \%$ after 3 months, and a further reduction to $18.5 \%$ after 6 months (28). The national program, however, has limited outreach since it is restricted to children below the 10th centile weightfor-age. Fortifying other foods presents problems, especially where subsistence farming is practiced and few commercially processed foods are purchased. For the few foods that are commonly purchased, such as sugar, many small factories are involved and so it is difficult to have a centralized system of fortification. Another potential intervention is to provide iron supplements through community-based projects (29-31).

Educational interventions have the potential of being a cost-effective approach for improving the diets of young children (32). The aim would be to increase the variety of foods consumed-particularly foods rich in iron-as well as the consumption of foods containing vitamin $C$ at every meal (33). Cooking in iron pots is no longer common in Pernambuco, but it could be encouraged $(34,35)$. Worm burdens among those under the age of 5 years are not known, but in four 
small villages in rural Pernambuco $82 \%$ of inhabitants above the age of 1 year had Schistosoma mansoni, 80\% had hookworm, and 70\% had Trichuris trichiura (12). These parasites cause blood and iron to be lost in the stool and thus can contribute to anemia. Research to determine the prevalence of intestinal parasites among children in urban and rural areas of Pernambuco is warranted. If such parasites are found to be common, then interventions should be implemented, particu- larly deworming and improved excreta disposal.

In summary, this research has highlighted anemia in the state of Pernambuco as a problem of public health importance requiring urgent action. Further research is necessary to determine which of the potential interventions is best suited to address the needs we have identified, particularly those of rural residents, who have more limited access to health care delivery systems.
Acknowledgments. This study was funded by the Instituto Nacional de Alimentação e Nutrição/Ministério da Saúde - Governo Federal do Brasil. Mônica Osório received a scholarship from CAPES (Fundação Coordenação de Aperfeiçoamento de Pessoal de Nivel Superior). The authors are grateful to those mothers and children who were the object of our research as well as to the field researchers and the technical team who participated in this study.

\section{REFERENCES}

1. United Nations Children's Fund. The state of the world's children. New York: UNICEF; 1998.

2. Lira PI, Cartagena HA, Romani, SAM, BatistaFilho M. Estado nutricional de crianças menores de seis anos, segundo a posse da terra, em áreas rurais do Estado de Pernambuco. Arch Latinoam Nutr 1985;35:247-257.

3. Assis AMO, Santos LMP, Martins MC, Araújo MPN, Amorim DQ, Morris SS, et al. Distribuição da anemia em pré-escolares do semi-árido da Bahia. Cad Saude Publica 1997; 13(2):237-243.

4. Diniz AS. Aspectos clínicos, subclínicos e epidemiológicos da hipovitaminose A no Estado da Paraíba [Ph.D. dissertation]. Recife, Brasil: Universidade Federal de Pernambuco, Centro de Ciências da Saúde, Departamento de Nutrição; 1997.

5. Monteiro CA, Szarfarc SC. Estudo das condições de saúde das crianças do município de São Paulo, SP (Brasil), 1984-1985: V-Anemia. Rev Saude Publica 1987;21:255-260.

6. Monteiro CA, Benício MHD, Iunes RF, Gouveia NC, Cardoso MAA. Evolução da desnutrição infantil. In: Monteiro CA, ed. Velhos e novos males da saúde pública no Brasil: a evolução do país e de suas tendências. São Paulo, Brasil: HUCITEC; 1995. pp. 93-140.

7. Instituto Brasileiro de Geografia e Estatística. Contagem nacional da população, 1996. Sistema IBGE de Recuperação Automática [Internet site]. Available from: http//www.sidra. ibge.gov.br. Accessed March 2001.

8. Instituto Nacional de Alimentação e Nutrição/Ministério da Saúde, Instituto Materno Infantil de Pernambuco, Departamento de Nutrição/Universidade Federal de Pernambuco, Secretaria Estadual de Saúde de Pernambuco. II Pesquisa Estadual de Saúde e Nutrição: saúde, nutrição, alimentação e condições sócio-econômicas no Estado de Pernambuco. Recife: INAM/MS-IMIP/DN-UFPE; 1998.

9. Victora C, Barros F. Epidemiologia da saúde infantil: um manual para diagnóstico comunitários. São Paulo: HUCITEC-UNICEF; 1991. Corporation; 1997.
10. Demaeyer E. Preventing and controlling iron deficiency anaemia through primary health care. A guide for health administrators and programme managers. Geneva: World Health Organization; 1989.

11. Stata Corporation. Statistics/data analysis [computer program]. Version 5.0. College Station, Texas, United States of America: Stata

12. Gonçalves JF, Tanabe M, Medeiros FPM, Gonçalves FJ, Aca IS, Motta SRN, et al. Parasitological and serological studies on amoebiasis and other intestinal parasitic infections in the rural sector around Recife, Northeast Brazil. Rev Inst Med Trop São Paulo 1990; 32(6):428-435.

13. Dallman PR, Reeves JD. Laboratory diagnosis of iron deficiency and iron. In: Stekel A, ed. Iron nutrition in infancy and childhood. New York: Raven; 1984. pp. 11-44

14. Karr M, Alperstain G, Cuser JC, Mira, M. Iron status and anaemia in preschool children in Sydney. Aust N Z J Public Health 1986;20: 618-622.

15. Beresford $\mathrm{CH}$, Neale RJ, Brooks OG. Iron absorption and pyrexia. Lancet 1971;20:568-562.

16. Guerrant LV, Kirchhoff DS, Shields MK, Leslie J, Souza MA, Araujo JC, et al. Prospective study of diarrheal illnesses in Northeast Brazil: patterns of disease, nutritional impact, etiologies, and risk factors. J Infect Dis 1983; 148:986-997.

17. Braut-Dulbuc M, Nadeau M, Dickie J. Iron status of French-Canadian children: a three year follow-up study. Hum Nutr Appl Nutr 1983;37A:210-221.

18. Viteri FE, De Tuna V, Guzman MA. Normal haematological values in the Central American population. Br J Haematol 1972;23;189-204.

19. Dallman PR, Siimes MA. Percentile curves for hemoglobin and cell volume in infancy and childhood. J Pediatr 1979;94:26-31.

20. Sherriff A, Emond A, Hawkins N, Golding J. Haemoglobin and ferritin concentration in children aged 12 and 18 months. Arch Dis Child 1999;80:153-157.
21. Hercberg S, Galan P. Nutritional anaemias. Baillieres Clin Haematol 1992;5:143-164.

22. Reeves JD, Yip R, Kiley VA, Dallman PR. Iron deficiency in infants: the influence of mild antecedent infection. J Pediatr 1984;105:874-879.

23. Cohen JH, Haas JD. The comparison of mixed distribution analysis with a three-criteria model as a method for estimating the prevalence of iron deficiency anaemia in Costa Rican children aged 12-23 months. Int J Epidemiol 1999;28:82-89.

24. Hercberg S, Chauliac M, Devanlay M, Galan P, Pureur JL, Soustre Y, et al. Evaluation of the iron status of a rural population in South Benin. Nutr Research 1986;6:627-634.

25. Owen GM, Yanochik-Owen MA. Should there be a different definition of anemia in black and white children? Am J Public Health 1977;67:865-866.

26. Garn SM, Smith NJ, Clark DC. Lifelong differences in hemoglobin levels between blacks and whites. J Natl Med Assoc 1975;67(2): 91-96.

27. Dallman PR, Barr G D, Allen CM, Shinefield HR. Hemoglobin concentration in white, black, and oriental children: is there a need for separate criteria in screening for anemia? Am J Clin Nutr 1978;31:377-380.

28. Torres MAA, Sato K, Queiroz SS. O leite em pó fortificado com ferro e vitamina $\mathrm{C}$ como medida de intervenção no combate à anemia carencial ferropriva em crianças atendidas em Unidade Básica de Saúde. Arch Latinoam Nutr 1996;46(4):113-117.

29. Schultink W, Gross R, Gliwitzki M, Karyadi D, Matulessi P. Effect of daily vs twice weekly iron supplementation in Indonesian preschool children with low iron status. Am J Clin Nutr 1995;61:111-115.

30. Palupi L, Schultink W, Achadi E, Gross R. Effective community intervention to improve hemoglobin status in preschoolers receiving once-weekly iron supplementation. Am J Clin Nutr 1997;65:1057-1061.

31. Thu BD, Schultink W, Dillon D, Gross R, Leswara DN, Khoi HH. Effect of daily and weekly micronutrient supplementation on 
micronutrient deficiencies and growth in young Vietnamese children. Am J Clin Nutr 1999;69:80-86.

32. Ashworth A, Feachem RG. Interventions for the control of diarrhoeal diseases among young children: weaning education. Bull World Heath Organ 1985:63(6):1115-1127.

33. Yip R. The challenge of improving iron nutrition: limitations and potentials of major inter- vention approaches. Eur J Clin Nutr 1997;51: S16-S24.

34. Borigato EVM, Martinez FE. Iron nutritional status is improved in Brazilian preterm infants fed food cooked in iron pots. J Nutr 1998; 128:855-859.

35. Adish AA, Esrey SA, Gyorkos TW, JeanBaptista J, Rojhani A. Effect of consumption of food cooked in iron pots on iron status and growth of young children: a randomised trial. Lancet 1999;353:712-715.

Manuscript received 10 November 2000. Revised version accepted 25 May 2001.

RESUMEN Objetivos. Determinar la prevalencia de la anemia en niños de 6 a 59 meses en Pernambuco, un estado del nordeste de Brasil, con el fin de ayudar a establecer las políticas de salud y nutrición.

Prevalencia de la anemia en niños de 6 a 59 meses en el estado de Pernambuco, Brasil
Métodos. En 1997 se determinaron las concentraciones de hemoglobina en una muestra representativa de 777 niños. El proceso de muestreo se realizó en tres fases. Primero se seleccionaron aleatoriamente 18 municipios representativos del estado y de sus tres zonas geográficas (la región metropolitana de Recife, el interior urbano y el interior rural). A continuación, utilizando las listas del censo, se seleccionaron aleatoriamente 45 sectores censales. Finalmente, se seleccionaron 777 niños de 6 a 59 meses de edad. La sangre se recogió por punción venosa y la hemoglobina se midió con un hemoglobinómetro portátil. En el análisis, la prevalencia fue ponderada en función de la distribución de edad del censo.

Resultados. La prevalencia de la anemia entre los niños de 6 a 59 meses fue del $40,9 \%$ en todo el estado, del 39,6\% en el área metropolitana de Recife, del 35,9\% en el interior urbano y del $51,4 \%$ en el interior rural. La prevalencia fue dos veces mayor en los niños de 6 a 23 meses que en los de 24 a 59 meses: 61,8\% frente a 31,0\% ( $\chi^{2}=77,9$, $P<0,001)$. Las concentraciones medias ( \pm una desviación estándar) de hemoglobina en estos dos grupos fueron de 10,4 $\pm 1,5$ y 11,4 $\pm 1,4 \mathrm{~g} / \mathrm{dL}$, respectivamente. La prevalencia no mostró diferencias estadísticamente significativas entre los dos sexos.

Conclusiones. Este ha sido el primer estudio de ámbito estatal realizado en Brasil sobre la prevalencia de la anemia en niños pequeños. La muy alta prevalencia de la anemia en los niños estudiados en Pernambuco, especialmente en los del grupo de 6 a 23 meses, requiere intervenciones de salud pública. 